\title{
RESEARCH ARTICLE \\ DIAGNOSTIC AND CHARACTERIZATION OF MATERIAL STATE FROM THE FIRST JEWS` ADOBE RANCH IN ALGARROBOS, CARLOS CASARES, BUENOS AIRES, ARGENTINA
}

\author{
Paula V. Alfieri*, Silvia Zicarelli, Graciela Molinari, Fabian Iloro and Luis P. Traversa \\ LEMIT (Laboratorio de Entrenamiento Multidisciplinario para la Investigación Tecnológica) Calle 52 e/ 121 y 122 (1900), La Plata, Argentina \\ *Corresponding Author E-mail: paulaalfieri@gmail.com
}

This is an open access article distributed under the Creative Commons Attribution License, which permits unrestricted use, distribution, and reproduction in any medium, provided the original work is properly cited.

\section{ARTICLE DETAILS}

\section{Article History:}

Received 01 August 2019

Accepted 11 September 2019

Available online 17 September 2019

\section{ABSTRACT}

In Buenos Aires, Argentina there are many architectonic heritage objects that represent the history of the population of different places with different degree of deterioration and conservation, so their study and survey were necessary to avoid the complete loss of it. During the study of heritage assets in towns, villages, and cities of Buenos Aires that the LEMIT makes more than 20 years ago, numerous architectonic heritage assets were found with different degree of deterioration and conservation. As result of some surveys, important restoration and conservation interventions were done preserving province heritage. Thus, the aim of this paper was the study of the materials deterioration state from the first ranch built by the settlement of the Jewish settlers in 1891, in Algarrobos city, Carlos Casares, Buenos Aires. This ranch was the first houses of Jews when they arrived from Russia. The material analysis here presented allowed to recognize its state of deterioration and conservation through discerning if these materials were from the mentioned age and consequently, providing fundamental information to know part of settlement history formation. On the other hand, its study allowed generating a plan of interventions and conservation in short - and medium- term.

\section{KEYWORDS}

Heritage, ranch, deterioration, conservation, materials.

\section{INTRODUCTION}

During the study of heritage objects and construction in towns, villages, and cities of Buenos Aires, numerous architectonic heritage assets were found with different degree of deterioration and conservation. One of them was found in March 2017, in a technical visit to Algarrobos (together with Heritage Director of Tourism and Museums of Carlos Casares Municipality) where heritage constructions conditions were examined and evaluated, Figure 1.
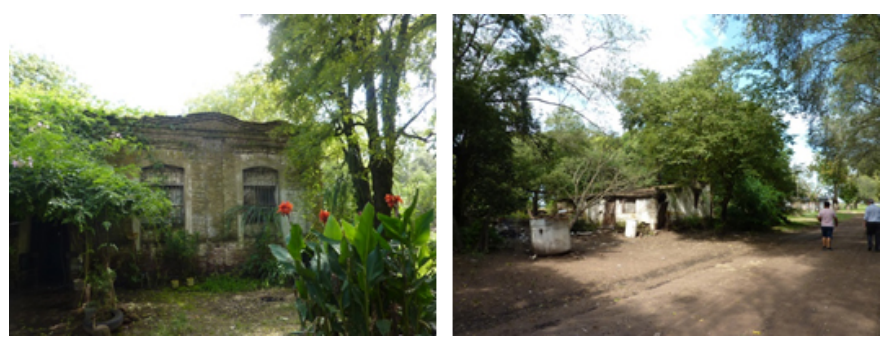

Figure 1: Algarrobos Colony, Carlos Casares, Buenos Aires, Argentina

In the visit the first ranch build was built in Algarrobos was found. It is located in the old Colonia Mauricio, Carlos Casares, province of Buenos Aires, Argentina, Figure 2. This build is an important due to that it is a reflex of an important historical event: the Jews establishment in Argentina. This historical event was linked to the massive Jewish immigration to our country, mainly from the Russian Empire, at the end of the 19th century. Nowadays, it is inside of the Buenos Aires tourist circuit [1-11].
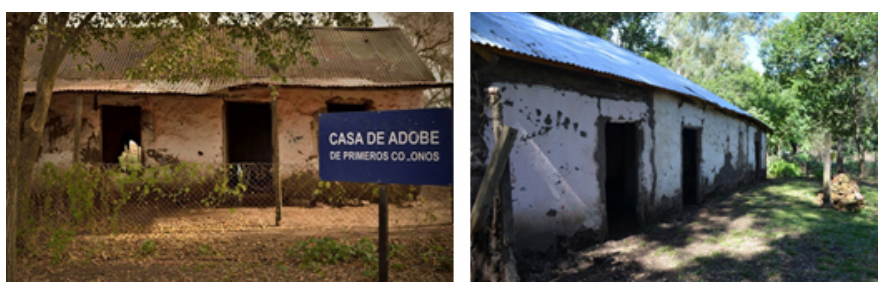

Figure 2: Adobe Ranch which was study

The settlement in Carlos Casares was due to immigration and colonization laws. In 1890, where Dr. Wilhelm Loewenthal, sent by Mauricio Hirsch, acquired 24,654 Hectares for the Jewish Colonization Association (JCA). This surface increased until reaching more than 43,000 Hs in the year 1902. This grown had a philanthropic purpose to save the inhabitants who professed the Jewish religion in Czarist Russia [12-23].

Jewish community immigration was due to the restrictive policy of the tsarist regime from the bloody 1881-1882 period that forced tens of thousands of Jews to leave their homes. In 1887, following the intensification of threats of expulsion of Jews from the western border areas of Russia, heads of families from the Kamenietz Podolsk (Podolia) region met to coordinate their own emigration.

The "Colonia Mauricio" was the first Jewish colony organized by the J.C.A. in the country: A group of 824 immigrants from the Jewish community arrived in 1891 at the station of Carlos Casares carrying only seeds (without any economic resources). This first group of the Colony occupied initially the land in which the Fort Algarrobos was located, bordering the lagoon with the same name. In an article published by Baron Hirsch (Jewish-German philanthropist, He was one of the main promoters of the Jewish colonies in America) said literally" I will try to create new homes in any region where, as free and honest farmers, on their own soil, they can become useful men for their adopted soil". Consequently, the first 
constructions were ranches made with materials that they found in empty lands: mud, wood, straw, and grass. One of these ranches was the object of this study, Figure 2. In 1920, much of the colonists obtain the titles of their properties thus, the Colonia Mauricio was designated as the most prosperous of the colonies of the J.C.A in Argentina [24-29].

Years later, different settlements had formed and Israelites, Italians and Spanish formed Carlos Casares town. In this territorial expansion of the settlers, many of the properties acquired sold to Spanish and Italian immigrants diversifying the place culture. This was reflected in the constructions found Carlos Casares city, such as the Italian theatre and the synagogue (Fig. 3). These constructions were brick and material, which date of 1920, contemporary to the expansion and diversification [16-29].
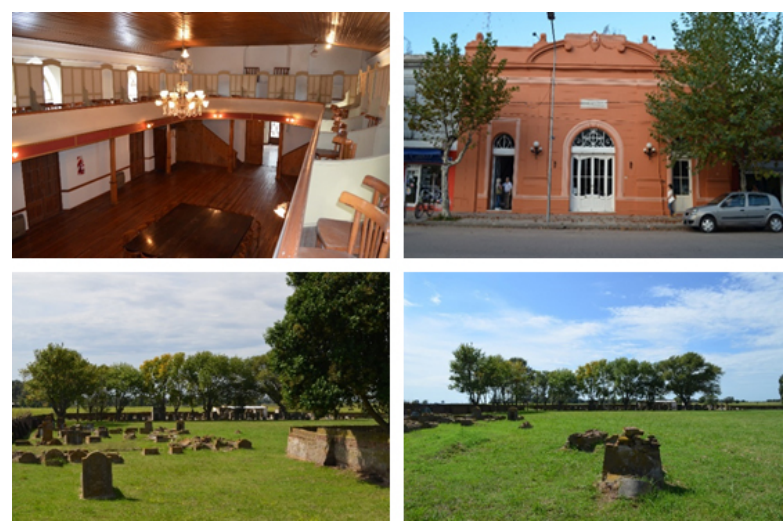

Figure 3: Synagogue and Italian Theatre, buildings of 1920 and Jewish Cemetery: views from and to the access

Nowadays the Colony became in four rural towns: Smith, Moctezuma, Mauricio Hirsch, and Algarrobos. In addition, there also is the cemetery, declared a Provincial Historic Site in 1991 for being the first Jewish cemetery in the province of Buenos Aires and the second in the country (Fig. 3).

For the aforementioned, the aim of this paper was the study of the materials belonging to the first ranch built by the settlers in 1891 in the colony of Algarrobos to be able to discern which of these materials were original of 1891, providing fundamental information to know the history of the population settlement in the site and generating a memory of its state of deterioration for future intervention for conservation.

\section{MATERIALS AND METHODS}

In the first instance, a visual analysis of the ranch`s materials were made. It was observed that it was done on adobe, a framework of wood and structurally reinforced with rod and wire mesh on the sides. The roof is sheet metal put in the restoration made in 2014 (Fig. 4). Minimum samples of the mentioned materials were taken (adobe, wire, and nails, wood and coatings).
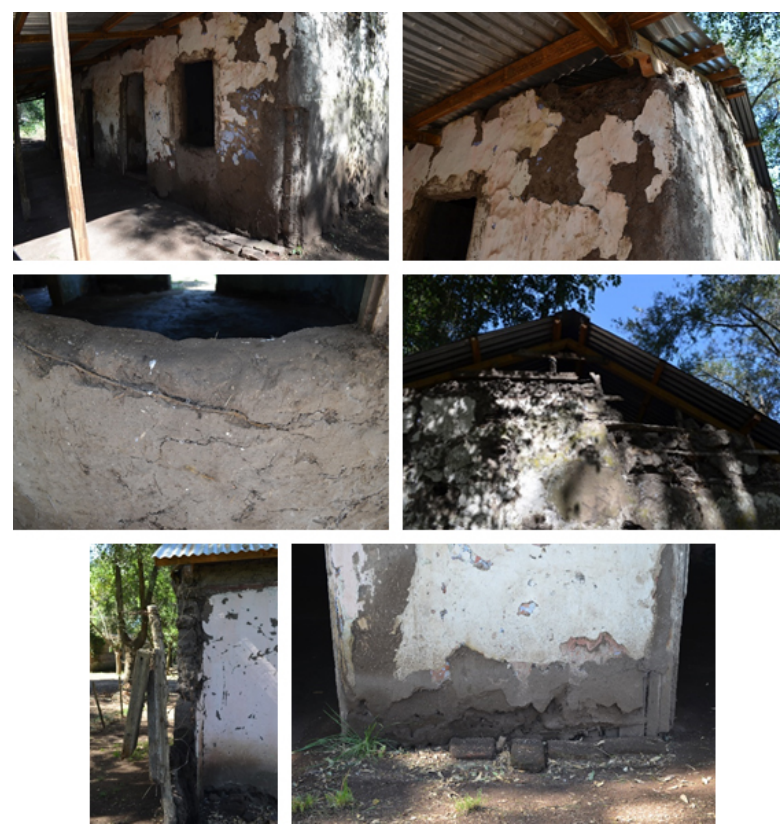

Figure 4: Construction details and materials of the Ranch
Adobe analysis consisted of the organic matter content determination, expansion, grain size analysis, colorimetry, and $\mathrm{pH}$ were determined.

On the other hand, wood species of ranch framework was determined by conventional methods of microscopy and taxonomic keys: observations of magnifying glass (10X) and microscope (40X) without staining, to observe characteristics in terms of vessels, parenchyma, and rays, which allowed the identification of species through the support of dichotomous keys [3032]. Then, it will be confirmed by comparing the woodcuts of the identified species.

Regarding the coating, minimum samples of the different layers were extracted by a superficial scraping with a spoonbill (Fig. 5). Samples were chemically analyzed by FT-IR (MATTSON Mod. GENESIS II spectrophotometer) with Attenuated Total Reflectance (ATR). The spectrograms were compared with spectrograms of Atlas "An Infrared Spectroscopy Atlas for the Coatings Industry" [33].
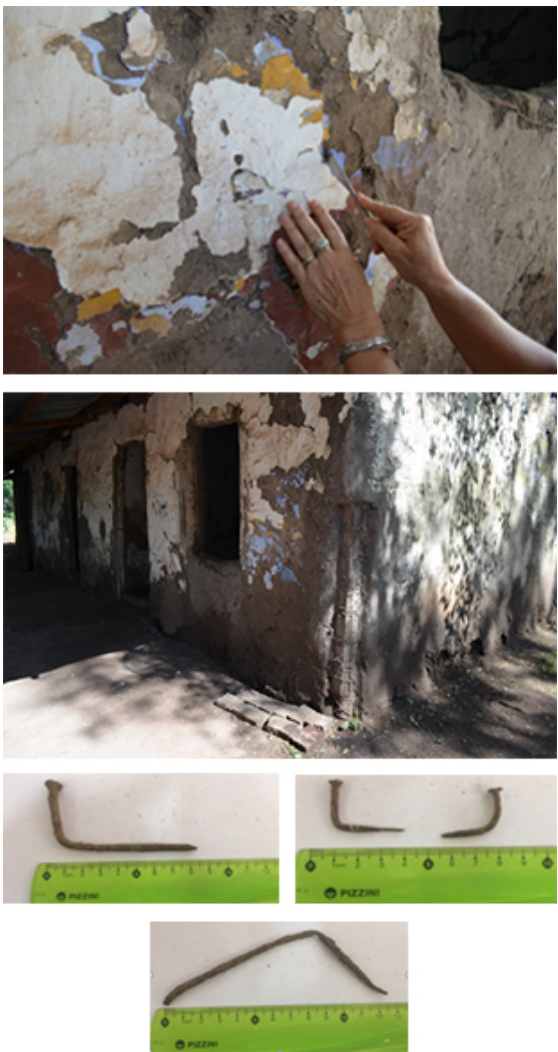

Figure 5: Wood, painting in the murals and metal elements found

With respect to the study of the nails and wire, metallic characterization was carried out under the guidelines of the ASTM E407-07 standard.

\section{RESULTS}

The adobe characterization was presented in Table 1 . The adobe had a grey mud (5YR3/1 dark when it is wet and lighter 5YR5/1 when it is dry) with a high content of expansive clays and a small proportion of grains of sand and silt size. In the thickest fraction (RT230) there were remains of contaminants such as fossil remains (crustaceans, molluscs, etc.) and brick of variable sizes ( $>1.3 \mathrm{~cm}$ in diameter) that show the anthropic activity of mentioned adobe. It should be remembered that the site is on the banks of a lagoon. The majority material was mud from the place (analysis of both were identical).

Table 1: Adobe characterization

\begin{tabular}{|l|l|}
\hline Humidity & $\mathbf{1 0 , 4 \%}$ \\
\hline $\begin{array}{l}\text { Organic Material content } \\
\text { (measured by calcination at } \mathbf{5 5 0} \\
{ }^{\circ} \mathbf{C} \text { for two hours) }\end{array}$ & $7 \%$ \\
\hline $\begin{array}{c}\text { Soil granulometry } \\
\quad \% \text { RT230 (grains }>\mathbf{6 3}\end{array}$ & $\mathbf{\mu m}$ ) \\
$\quad \mathbf{\% P T 2 3 0}$ (grains $<\mathbf{6 3} \boldsymbol{\mu m}$ ) & $10,2 \%$ \\
\hline Soil expansion (Free Swell Test) & $89,9 \%$ \\
\hline $\mathbf{p H}$ & $81,6 \%$ \\
\hline
\end{tabular}


On the other hand, wood microscopy observations were carried out. It indicated that the wood species was Quebracho Blanco (Aspidosperma Quebracho Blanco). This species was characteristic of the north of Argentina and it was much utilized on that period by vapour railways [3032]. On the other hand, active biodeterioration was found, majority a patron corresponding to soft rot, Figure 6.

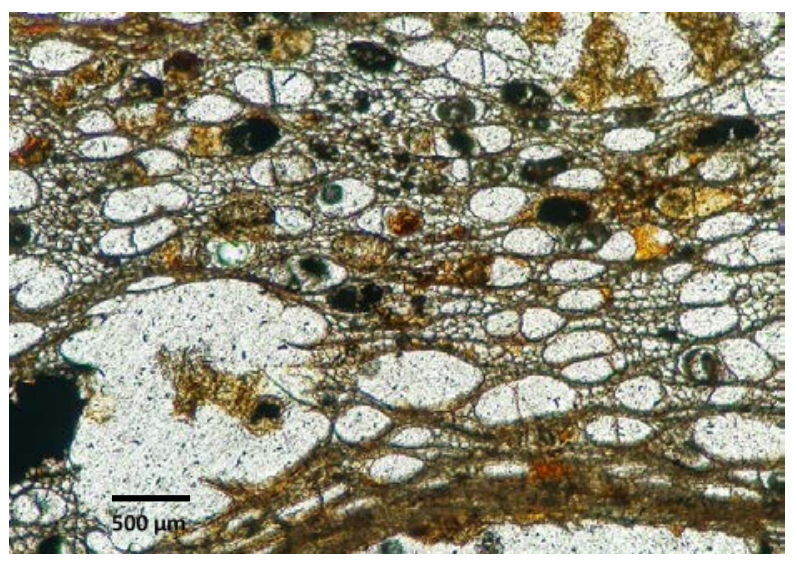

Figure 6: Biodeteriorated wood under microscope

Regarding the coating layers (Fig. 7), it was observed that the compound utilized as a binder was $\mathrm{Ca}(\mathrm{OH})_{2}$ in all the layers ("lime" coatings group). $\mathrm{CaCO}_{3}$ is designated by bands: $1426 \mathrm{~cm}^{-1} ; 875 \mathrm{~cm}^{-1}$ and $712 \mathrm{~cm}^{-1}$ [33]. This was an interesting fact meanwhile the first coating layer was based on lime, so the others continue with this binder because it wouldn't be compatible with other subsequent coatings.

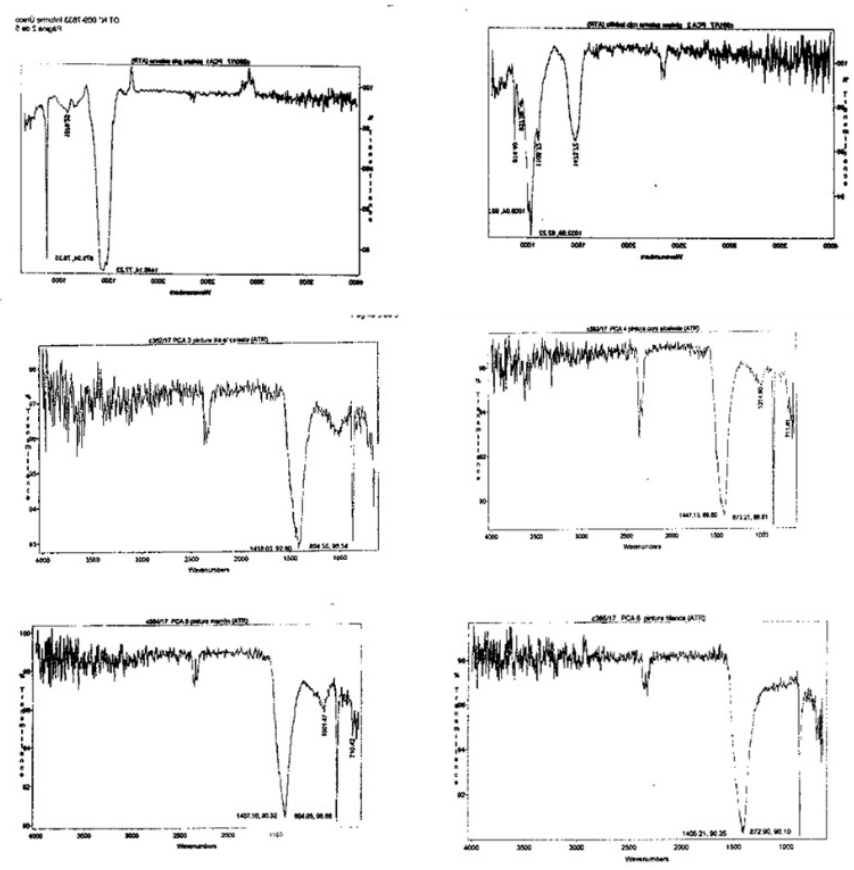

Figure 7: FTIR of coating layers

Concerning coating pigments, it was observed that the most external coating (grey) had a mixture of pigments: one of black colour (BONE BLACK: Ca $\left(\mathrm{PO}_{4}\right)_{2} /$.CARBON, Spectrogram No. 839), and another one of white colour $\left(\mathrm{CO}_{3} \mathrm{Ca}\right.$, Spectrogram $\left.\mathrm{N}^{\circ} 796\right)$ in equal proportions. With respect to the red one, it had an inorganic pigment, formed by a mixture of Iron Oxides $\left(\mathrm{Fe}_{2} \mathrm{O}_{3}\right)$ and Silicates, commercially known as RAW SIENNA designated by $1620 \mathrm{~cm}^{-1} ; 1113 \mathrm{~cm}^{-1} ; 1032 \mathrm{~cm}^{-1} ; 915 \mathrm{~cm}^{-1}$ and $793 \mathrm{~cm}^{-1}$ bands, spectrogram 921 [33]. It indicated that it was a more recent coating matching with layer location.

On the other hand, the pale-blue layer linked to an inorganic pigment Sulfo Aluminum Silicate known commercially as Ultramarine Blue. The bands were $1634 \mathrm{~cm}^{-1}$ and $1026 \mathrm{~cm}^{-1}$, spectrogram 854 [33].

The brown pigmentation of the other layer corresponded to an inorganic pigment formed by a mixture of oxides of Iron, Chrome and Zinc, commercially known as Ferro Light Brown, that was designated by 1633 $\mathrm{cm}^{-1} ; 1030 \mathrm{~cm}^{-1} ; 911 \mathrm{~cm}^{-1} ; 792 \mathrm{~cm}^{-1}$ and $655 \mathrm{~cm}^{-1}$ bands, spectrogram 864 [33].

Finally, the white layer corresponds to pure lime pigment (Calcium Carbonate, spectrogram 796 [33]).

Concerning to metallography study, it was carried about by metal microscopy without and with NITAL (Nitric acid between $2 \%$ in ethylic alcohol) attack, Figure 8. In figure without attack, it was observed nonmetallic inclusions aligned by plastic deformation due to the manufacturing process (longitudinal view). These inclusions were determined by ASTM E45 obtained that they were if alumina.
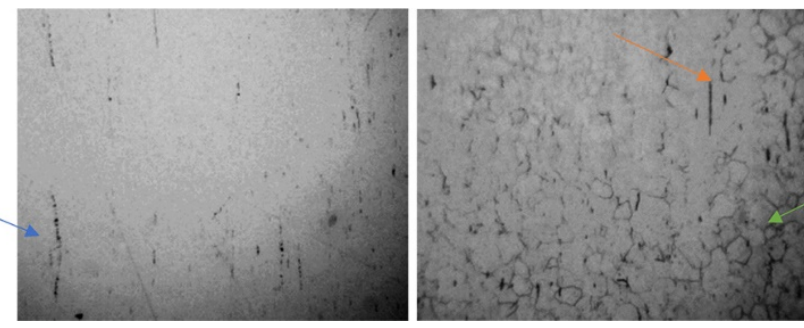

Figure 8: Metal analysis. Blue arrow indicated alumina inclusion; orange arrow, sulphur inclusion (ASTM E 45) and green arrow indicated perlite structure

In Figure 8 with the attack, it was also observed low perlite structure (ferrite and cementite in laminated aggregates) and sulphur non- metallic inclusions (ASTM E45). In addition, the metal microstructure observed denote that the metal found had low steel content $(<0.10 \%)$.

\section{DISCUSSION}

All pigments had dated of the period of the ranch was build. So, both restoration records observed, and this FT-IR analysis allowed concluding that coating belongs to the colonist's age and not of the contemporary restoration [29].

The metal inclusions were relevant because it marks indirectly the metal age. It was due to the Siemens-Martin process (the open-hearth furnace) developed by German engineer (Carl Wilhelm Siemens) in 1865. This steel development process included an "open-hearth" furnace, which allowed to obtain elevated fusion temperature. This last allowed that the oxygen in iron oxide and other impurities were decarburized the pig iron by burning excess carbon away, forming clean steel. So, if metal was clean of inclusions it was the development from after 1865 [34].

For the aforementioned, it concluded that the wire and nails were of the late nineteenth or early twentieth-century steel, due to the degree of cleanliness of the steel, contemporary with the colonization of the area.

Finally, is worth to mentioned that the wood species found in the structural framework of the ranch is moreover the same species that found in a wooden tomb-marker study before [34]. In addition, many of pigments found in the ranch were accordingly with that found on some sectors of the cemetery. So, there is a concordance in the use of these pigments in the colony, translating to the time when it began to emerge. Therefore, it allowed concluding that both constructions were contemporaneity which is very important to construct the social story of population formation.

In addition, the study allowed to differentiate the original from the modified by restorations, as well as obtained the state of conservation of the heritage asset fundamental for future interventions.

\section{CONCLUSIONS}

The study of the materials founded in the ranch allowed obtaining them age information, and with this, if they were original of the colonists.

It was concluded that the study of the materials and their composition allow discerning the age of these. In addition, the study allowed to differentiate the original from the modified by restorations, as well as obtained the state of conservation of the heritage asset fundamental for future interventions.

This allows concluding that the ranch has original materials from the time was built, as many primary materials (adobe, nail, wire, and wood) as protection (coating) in an acceptable deteriorate state. But it needs a conservation process as soon as possible due to a biodeterioration active process found. 
Nowadays, in Casares remaining very few Jews, most of them are already old people, thus the youngest ones are beginning to work in the recovery and restoration of these sites with so much history.

\section{ACKNOWLEDGMENTS}

To Teresa Acedo, Director of Heritage, Tourism and Museums of the Municipality of Carlos Casares, Dra. Yamile Rico, Dr. Ricardo Gregorutti and Daniel Alves for the collaboration in this work carried out within the framework of the Project "State of conservation of the architectural heritage: Techniques of repair and promotion of possible tourist circuits in localities, towns and cities of the province of Buenos Aires "subsidized by the CICPBA within the program" Innovation and Transfer Projects in Priority Areas of the Province of Buenos Aires", Directory resolution $\mathrm{N}^{\circ}$ $428 / 16$

\section{REFERENCES}

[1] Ratto, S.M. 2012. Estado, vecinos e indígenas en la conformación del espacio fronterizo: Buenos Aires, 1810-1852, 2o Ed., Corpus. Archivos virtuales de la alteridad americana, Argentina, 1-483.

[2] García, P.A., Reyes, J.M., De Angelis, P.S. 1969. Diario de la expedición de 1822 a los campos del Sud de Buenos Aires desde Morón hasta la sierra de la Ventana. Colección de obras y documentos relativos a la historia antigua y moderna de las Provincias del Río de la Plata. Vol. 4. Buenos Aires, 395-671.

[3] García, P.A. 1974. Diario de un viaje a Salinas Grandes, en los campos del sud de Buenos Aires. Eudeba, Buenos Aires, 113

[4] Banzato, G. 2000. De ocupantes a propietarios, los conflictos entre vecinos de la frontera bonaerense. Chascomús y Ranchos, 1800-1840, Quinto Sol, Universidad Nacional de La Pampa, (4), 11-38

[5] Jalif de Bertranou, C.A. 2006. Argentina en El Espejo. Sujeto, Nación y Existencia en el Medio Siglo 1900-1950. Ed. Universidad Nacional de Cuyo, $1-513$

[6] Sarthou, N. 2006. An approach to legitimation in the scientific field of international relations in Argentina (1958-1990). Rev. Bras. Hist. Ciênc., (2), 296-314

[7] Gelman, J. 2000. Crisis y reconstrucción del orden en la campaña de Buenos Aires. Estado y sociedad en la primera mitad del siglo XIX, Boletin de Historia Argentina y Americana Dr. Emilio Ravignani, 21, UBA, Buenos Aires, 63.

[8] Lesser, R. 2005. Los orígenes de la Argentina. Biblos. Historia Argentina: Historia Argentina de Jose Luis Busaniche Editorial: Taurus, Argentina, 792.

[9] Lesser, R. 2003. Los orígenes de la Argentina: Historias del reino del Río de la Plata Editorial Biblos, Buenos Aires. Argentina, 267

[10] Acedo, T. 1991. Relevamiento y restauración del Cementerio de Algarrobos-Colonia Mauricio. Carlos Casares. Buenos Aires. Argentina. MS.

[11] Acedo, T. 1991. Un acercamiento al Fortín Algarrobos. Relevamiento y restauración del Cementerio de Algarrobos-Colonia Mauricio (m.s.), Pautas y acciones es la restauración de la Sinagoga de Moctezuma, Municipalidad de Algarrobos, Colonia Mauricio, Argentina.

[12] Zablotsky, E. 2012. Filantropia no asistencialista: la reseña de Demetrio Aranovich sobre Colonia Mauricio. Documento de Trabajo 484, Universidad del CEMA Argentina, 63.

[13] Garfunkel, B. 1960. Narro mi Vida, 275.

[14] Aranovich, D. 2002. Colonia Mauricio. Reseña Histórica, Mundo Israelita 444, 445 y 446; 12, 19 y 26 de diciembre de 1931. Reimpreso en Breve Historia de la Colonia Mauricio, Editora del Archivo, Archivo Histórico Antonio Maya, Carlos Casares, Argentina, 13 - 20.

[15] Alpershon, M. 1928. Colonia Mauricio, 3o ed. (manuscrito traducido por Eliahu Toker), 2.
[16] Iedidio, E. 1939. La Obra Escolar en las Colonias Judías, 50 Años de Colonización Judía en la Argentina, Delegación de Asociaciones Israelitas Argentinas, 241-262.

[17] Levin, Y. 2017. Las primeras poblaciones agrícolas judías en la Argentina (1896-1914) Crisis y expansión de las colonias fundadas por The Jewish Colonization Association. Colección UAI - Investigación, Editorial Teseo, Argentina, 476.

[18] Winsberg, M.D. 1969. Jewish Agricultural Colonization in Entre Rios, Argentina. Amer. J. Econom. Sociol., 1, 27(3), 285-295.

[19] Hirsch, B. 1981. My Views on Philanthropy, North American Review, $153,416$.

[20] Martín, A. 2005. Colonia Mauricio, Memorias de un Colono JudíoComisión Folclore en las grandes ciudades: arte popular, identidad y cultura Ed. Libros del Zorzal, Argentina, 251.

[21] Salerno, E. 2008. Los Ferrocarriles del Estado en Argentina y su contribucióna la ciencia. História, Ciências, Saúde -Manguinhos, Rio de Janeiro, 15(3), 657-678.

[22] Sigal, S. 1972. Historia de Carlos Casares. Diario, El Oeste, Argentina.

[23] Sigwald, C.S. 1991. Colonia Mauricio: Revalorización de su trascendencia, en Gersenobitz, Juan Mario (coord.), Colonia Mauricio, 1421.

[24] Leoni, J.B., Acedo, T., Tamburini, D. 2011. y G. Scarafia, Cambio y continuidad en la materialidad funeraria del cementerio judío Algarrobos Colonia Mauricio (Carlos Casares, Provincia de Buenos Aires). Rev. Arqueol. Hist. Arg. Latinoamer, 5, 35-65.

[25] Acedo, T., Schteimberg, D. 2005. Cementerio judío de Algarrobos, Sitio Histórico Provincial. Relevamiento e identificación de datos. Carlos Casares. Buenos Aires. Argentina. MS

[26] Anderson, T.G. 1993. Czech-Catholic cemeteries in East-Central Texas: material culture and ethnicity in seven rural communities. Mat. Cult., 25(3), 1-18.

[27] Sigwald, C.S. 1991. Colonia Mauricio, Génesis y Desarrollo de un Ideal $2^{\circ}$ ed., Editora del Archivo, Centro Cultural José Ingenieros, Archivo Histórico Antonio Maya, Carlos Casares.

[28] Weill, S. 1939. Las colonias agrícolas de la Jewish Colonization Association. Reseña geográfica, económica e histórica, en 50 años de colonización judía, Argentina, 145-198.

[29] Delamare, F., Guineau, B. 2000. Discoveries: Colors: The Story of Dyes and Pigments, Harry N. Abrams Ed., Universidad de Virginia, 159.

[30] Jiménez, A.M., Moglia, J.G. 2003. Árboles del Chaco Argentino: Guía para el Reconocimiento Dendrológico, 370. ISBN 987 95852-9-1.

[31] Tortorelli, L. 1956. Maderas y Bosques Argentinos; Editorial ACME: Buenos Aires, Argentina, 1-95, 910.

[32] Tortorelli, L. 1963. Glosario de Términos en Anatomía de Maderas; Revista de Inventario Foresta IIV №1; Administración Nacional de Bosques de Buenos Aires: Buenos Aires, Argentina, 3-32.

[33] Brezinski, D.R. 1991. An infrared spectroscopy atlas for the coatings industry Chicago Society for Coatings Technology Infrared Spectroscopy Committee. Editorial: Blue Bell, Federation of Societies for Coatings Technology, 500

[34] Siemens, C.W. 1862. On a regenerative gas furnace, as applied to glasshouses, puddling, heating, etc. Proceedings of the Institution of Mechanical Engineers, 13, 21-26.

[35] Alfieri, P.V., Lofeudo, R., Iloro, F., Canosa, G., Traversa, L. 2018 Conservation of a wooden tomb-marker from the Jewish cemetery of Algarrobos in Argentina, Heritage, 1(1), 47-56. 